\title{
Microstructural and Erosive Wear Characteristics of a High Chromium Cast Iron
}

\author{
Annalisa Fortini *(D), Alessio Suman (D, Alessandro Vulpio, Mattia Merlin (D) and Michele Pinelli \\ Department of Engineering, University of Ferrara, 44122 Ferrara, Italy; alessio.suman@unife.it (A.S.); \\ alessandro.vulpio@unife.it (A.V.); mattia.merlin@unife.it (M.M.); michele.pinelli@unife.it (M.P.) \\ * Correspondence: annalisa.fortini@unife.it
}

check for

updates

Citation: Fortini, A.; Suman, A.; Vulpio, A.; Merlin, M.; Pinelli, M. Microstructural and Erosive Wear Characteristics of a High Chromium Cast Iron. Coatings 2021, 11, 490. https://doi.org/10.3390/ coatings 11050490

Received: 30 March 2021

Accepted: 19 April 2021

Published: 22 April 2021

Publisher's Note: MDPI stays neutral with regard to jurisdictional claims in published maps and institutional affiliations.

Copyright: (c) 2021 by the authors. Licensee MDPI, Basel, Switzerland. This article is an open access article distributed under the terms and conditions of the Creative Commons Attribution (CC BY) license (https:// creativecommons.org/licenses/by/ $4.0 /)$.

\begin{abstract}
Surface material loss due to erosive wear is responsible for the increased cost of maintenance and downtime in industries. Hence, hardfacing is one of the most valuable and effective techniques employed to improve the wear resistance of heavy-duty components. The present paper investigates the microstructural and erosive wear characteristics of a hypereutectic high-chromium cast iron, considering the erosion resistance, resulting from the impact of micro-sized particles, of both as-received and heat-treated conditions. Micro-sized particles involve the erosion-resistant characteristics of carbide and matrix, contemporary. Due to this, the enhancement of the matrix strength could improve the mechanical support to withstand cracking deformation and spalling. Accordingly, the effect of a destabilization heat treatment on the microstructure was firstly investigated by hardness tests, $\mathrm{X}$-ray diffraction analyses, optical and scanning electron microscopy. Specifically designed erosive tests were carried out using a raw meal powder at an impingement angle of $90^{\circ}$. The resulting superior wear resistance of the heat-treated samples was relayed on the improved matrix microstructure: consistent with the observed eroded surfaces, the reduced matrix/carbides hardness difference of the heat-treated material is pivotal in enhancing the erosion resistance of the hardfacing. The present results contribute to a better understanding of the microstructure-property relationships concerning the erosive wear resistance.
\end{abstract}

Keywords: hardfacing; high chromium cast iron; heat treatment; erosion tests; wear resistance

\section{Introduction}

A widespread solution in industrial applications to extend the service life of components, in machinery equipment or construction, is found in cladding certain areas of the surface exposed to various severe wear conditions. Within the different surface coating protective and hardening techniques, hardfacing is one of the most adopted due to its low-cost and easy handling characteristics [1,2]. Hardfacing enables enhancing the corrosive, abrasive, and heat resistance properties of a metal workpiece's surface, creating a cladding metal layer with improved features [3]. Iron-based hardfacing alloys are the most widely-used thanks to their good wear resistance and low cost. Among these, due to their superior wear resistance, High Chromium Cast Irons (HCCIs) are broadly employed in both abrasive (e.g., grinding media) and erosive (e.g., slurry, gravel, and dredge pumps) applications [2]. Accordingly, HCCIs are widely used in minerals and mining industries, cement plants, paper and pulp industry, thermal power plants, iron and steel industries, etc.

Considering that hardfacing is usually deposited on the substrate by welding techniques, the microstructure of $\mathrm{Fe}-\mathrm{Cr}-\mathrm{C}$ hardfacing alloys resulting from a non-equilibrium solidification process consists of a Fe-Cr solid solution phase and complex carbides, depending on the $\mathrm{Cr}$ and $\mathrm{C}$ contents of the alloys. $\mathrm{Cr}$-rich cast irons with hypereutectic structure, i.e., primary $M_{7} C_{3}$ carbides surrounded by eutectic austenite and $M_{7} C_{3}$ carbides [2,4-6], show high hardness and superior wear resistance to the hypoeutectic ones. The excellent abrasion resistance of hypereutectic alloys stems from the dispersion of the 
hard (1300-1800 HV) $\mathrm{M}_{7} \mathrm{C}_{3}$ eutectic carbides [7,8]. Despite that, the as-cast condition of hypereutectic HCCIs cannot meet the demand of heavy impact conditions due to the difference in hardness between the matrix and the carbides. Hence, while on the one hand hypoeutectic HCCIs are still used in high demanding environments, on the other hand, efforts are devoted to enhancing the wear resistance of both hypo- and hyper-eutectic alloys [9]. HCCIs may be regarded as composite materials as they show a structure composed of large eutectic $\mathrm{M}_{7} \mathrm{C}_{3}$ carbides in a softer iron matrix. Hence, a good combination between matrix and carbides' hardness and toughness should be tuned to enhance the overall resistance [10].

Many studies have been focused on the improvement of wear resistance of HCCIs by the addition of strong carbide forming elements such as $\mathrm{W}$ [11,12], $\mathrm{V}$ [13], $\mathrm{Nb}$ [14,15], Ti [16], Mo $[17,18]$, and B. Alloying elements are added to the melt to promote the precipitation of abrasion-resistance $\mathrm{MC}$ carbides ( $\mathrm{M}$ is the metal and $\mathrm{C}$ is the carbon), stronger and harder than $\mathrm{M}_{7} \mathrm{C}_{3}$ ones [19-22]. At the same time, attention has been paid to the size, distribution, and volume fraction of carbide phases that overall affect the wear resistance of the alloy [23].

Moreover, the toughness and the strain hardening behavior of the matrix influence the wear resistance of the hardfacing since it should provide the mechanical support to withstand cracking deformation and spalling [7]. Several attempts have been made to improve the tribological and wear behavior of HCCIs through heat treatments [10,24-26] and mechanical treatments [27]. In the as-cast condition, the matrix is mainly austenite that, upon specific thermal treatments, is transformed into martensite. While the primary carbides formed inside the melt after casting and the eutectic carbides formed at about $1250{ }^{\circ} \mathrm{C}$ are not altered by heat treatment, the metastable austenite transforms to martensite through proper destabilization and subcritical treatments. To induce austenite to martensite phase transformations and, in turn, the overall hardness increment, heat treatments comprise heating for $1-6 \mathrm{~h}$ in the range of $900-1100{ }^{\circ} \mathrm{C}$ are usually applied [28].

In the last few decades, much research has been devoted to explaining the role of microstructural characteristics in the wear behavior of hardfacing alloys through specific wear tests (i.e., pin-on-disk or wheel, slurry erosion test, impact erosion resistance) [29-33]. Renewed attention has been paid to the impact erosion resistance of white cast irons, investigated through solid particle erosion tests [3,9,24,34-36]. Data from several studies have proved that wear resistance is not mainly influenced by the bulk hardness of the material, but it is a complex phenomenon derived from several factors, like type, volume fraction, size, and morphology of eutectic carbides together with their interaction with the matrix [7,37]. Moreover, the microstructural modifications of the matrix resulting from different heat treatments applied to destabilized the austenite are pivotal in the assessment of the wear resistance performance. Finally, to the authors' knowledge, there is no evidence about research on the wear behavior of HCCIs subjected to impact erosion tests with micrometric particles with diameters in the range of 1-10 $\mu \mathrm{m}$, commonly used in the industrial process but very different from the standard powder used for erosion tests.

In the light of the above, the main objective of the present study is to investigate the microstructural features and wear erosive behavior of a commercially available hypereutectic HCCI. Accordingly, this paper begins with a synopsis of the literature regarding HCCIs and, more specifically $\mathrm{Fe}-\mathrm{Cr}-\mathrm{C}$ hardfacing alloys, to highlight the microstructural features responsible for their tribological behavior. The second section describes the adopted methods to assess the chemical, microstructural and mechanical features of the hardfacing alloy. Moreover, the erosion tests conducted through a dedicated test rig and the effect of a destabilization heat treatment on the microstructure and, in turn, on the erosion resistance, are explained. The third section of the paper describes the microstructural characterization of the hardfacing alloy, of nominal composition $\mathrm{Fe}-22 \mathrm{Cr}-4.8 \mathrm{C}$ wt. $\%$, brings together the findings of hardness tests, optical microscopy, electron scanning microscopy and X-ray diffraction analyses. Further, considering the role of microstructural features on the wear properties of the alloy, the destabilization of austenite, through a heat treatment at $950{ }^{\circ} \mathrm{C}$ 
for $3 \mathrm{~h}+$ oil quenching conducted to promote martensite formation and secondary carbides precipitation, is presented. The wear behavior of the as-received and heat-treated samples is investigated through a dedicated test rig, by simulating the operating condition of the considered HCCI alloy used in a large-sized centrifugal fan [38]. The observed improved erosion resistance is described and discussed. Lastly, the fourth section summarizes the main findings of the research study. The novelty of the present paper is related to the investigation of the wear-resistant behavior of the hardfacing alloy, before and after heattreatment, used to overcome the erosion effects due to the impact of micro-sized particles. This latter characteristic has to be considered not only against the carbide hardness but also on the carbide morphology and matrix characteristics. This experimental study does not engage with a comprehensive evaluation of the destabilization temperature and time parameters that could be tuned to improve the erosive wear resistance of the investigated HCCI alloy. Likewise, it is beyond the scope of this preliminary study to examine the role of carbide spacing against the particle size distribution of the erodent powder.

\section{Materials and Methods}

The hardfaced plate analyzed in this study is a layer-composite wear plate, commercially available as EIPA 550 (Eipa Eisen Palmen GmbH, Aachen, Germany), made by the open-arc welding of a flux-cored wire. The HCCI hardfacing electrodes were deposited on a low carbon steel plate. The nominal thickness of the base steel, as well as of the hardfacing, is $5 \mathrm{~mm}$. The chemical composition of the welded layer and the substrate were determined through the Glow Discharge Optical Emission Spectrometry (GD-OES, Spectruma Analitik GDS 650, Hof, Germany) technique. Table 1 reports the chemical composition of the alloys: note that for the HCCI the composition was analyzed in the cross-section considering both an acquisition area near the resistant side (at about $500 \mu \mathrm{m}$ far from the top surface), named RS, and an acquisition area near the substrate side (at about $4500 \mu \mathrm{m}$ far from the top surface), named SS. The HCCI is an $\mathrm{Nb}$ - and Mo-rich alloy, with a $\mathrm{Cr} / \mathrm{C}$ ratio of about 5 .

Table 1. Chemical composition (wt.\%) of the hardfacing plate.

\begin{tabular}{ccccccccc}
\hline \multirow{2}{*}{ Site } & \multicolumn{7}{c}{ Composition (wt.\%)-Fe Balance } \\
\cline { 2 - 9 } & C & Mn & Si & Cr & Mo & Nb & W & V \\
\hline HCCI-RS & 4.15 & 0.56 & 1.08 & 21.04 & 2.78 & 4.09 & 0.86 & 0.69 \\
HCCI-SS & 3.83 & 0.59 & 1.13 & 18.59 & 2.59 & 3.75 & 0.89 & 0.65 \\
Carbon steel-Substrate & 0.13 & 0.70 & 0.19 & 0.03 & 0.33 & - & - & - \\
\hline
\end{tabular}

The microstructure of the hardfacing alloy was evaluated by sampling longitudinal sections, named L (parallel to the direction of welding), and cross-sections, named $\mathrm{T}$ (perpendicular to the direction of welding), following the basic steps for proper metallographic analysis, i.e., cutting, mounting in resin, grinding, final polishing and etching. The latter was conducted by Kalling's No. 2 reagent $\left(5 \mathrm{~g} \mathrm{CuCl}_{2}, 100 \mathrm{~mL} \mathrm{HCl}, 100 \mathrm{~mL} \mathrm{C}_{2} \mathrm{H}_{5} \mathrm{OH}\right)$ to reveal the microstructure: the samples were immersed in the reagent for $5 \mathrm{~s}$, rinsed with ethanol, and air-dried. Metallographic investigations were conducted through a Leica DMi8A (Leica, Wetzlar, Germany) optical microscope (OM) and a Zeiss EVO MA 15 (Zeiss, Oberkochen, Germany) scanning electron microscope (SEM), equipped with an Oxford X-Max 50 (Oxford Instruments, Abingdon-on-Thames, UK) energy dispersive microprobe for semi-quantitative analyses (EDS). The SEM micrographs were recorded in secondary electron imaging (SEI-SEM) and back-scattered electron (BSE-SEM) modes.

Crystallographic phase identification was performed by X-ray diffractometry (XRD) with a Bruker D8 Advance (Bruker, Billerica, MA, USA) diffractometer, equipped with a $\mathrm{Cu}$ filament $(\mathrm{K} \alpha, 1.5406 \AA)$. All patterns were acquired in the $2 \theta$ range of $30^{\circ}$ to $80^{\circ}$ with $0.02^{\circ}$ of step-size and $1 \mathrm{~s}$ of step time.

Quantitative metallographic analyses, after preliminary post-processing of the optical micrographs, using the MATLAB ${ }^{\circledR}$ Color Thresholder app and then evaluation through 
the Leica LAS (Leica Application Suite) V4.9 software, enabled to examine the Carbide Volume Fraction (\% CVF). For each sample, the analyzed region comprised a total of 20 micrographs for the SS and the RS, respectively.

Bulk hardness measurements were carried out on the polished cross-sections of the samples to evaluate the variation in hardness from the resistant side of the hardfacing to the steel substrate of the wear plate. The Vickers hardness measurements, under $1000 \mathrm{~g}$ test load and 15 s loading time (HV1), were carried out by a Future-Tech FM-110 (Future-Tech Corp., Kawasaki, Japan) Vickers indenter, in agreement with the ASTM E92 standard. Moreover, Vickers microhardness on the T cross-sections of the polished and etched hardfacing alloy was also evaluated on both the matrix (test load of $200 \mathrm{~g}$ and $15 \mathrm{~s}$ loading time, HV0.2) and on the carbides (test load of $50 \mathrm{~g}$ and $15 \mathrm{~s}$ loading time, HV0.05). In all cases, the mean Vickers hardness was calculated from five indentations.

Erosion tests were carried out using an on-purpose built test rig inspired by the ASTM G76 standard [39]. Since the present analysis was conceived to explore the erosion behavior due to a micro-sized powder, the feeding systems, as well as the nozzle, were modified with respect to the prescribed ones to ensure a constant feeding rate and avoiding clogging phenomenon during the test. The raw meal powder considered in this investigation was experimentally characterized to define particle morphology, size distribution and physical characteristics. The erosion tests were carried out by a raw meal powder commonly used in a cement factory, able to form several agglomerates due to humidity. Digital and SEI-SEM images of a powder sample in the as-received condition are displayed in Figure 1a,b. The overall average density of the powder was evaluated by an AccuPyc II 1340 (Micromeritics Instrument Corporation, Norcross, GA, USA) pycnometer and it results equal to $2700 \mathrm{~kg} / \mathrm{m}^{3}$. Moreover, a quantitative analysis of particle diameter distribution is carried out to evaluate the presence of different diameter particles $\left(d_{p}\right)$ within the powder. The particle size distribution is determined by a Mastersizer 3000 laser diffraction analyzer (Malvern Panalytical, Malvern, UK) and it is depicted in Figure 1c, which reports the number, labeled as $\mathrm{N}$, and mass distributions, labeled as $\mathrm{M}$, of the powder. The raw meal powder was characterized by an average diameter of $4.3 \mu \mathrm{m}\left(d_{90}=9.7 \mu \mathrm{m}\right)$.
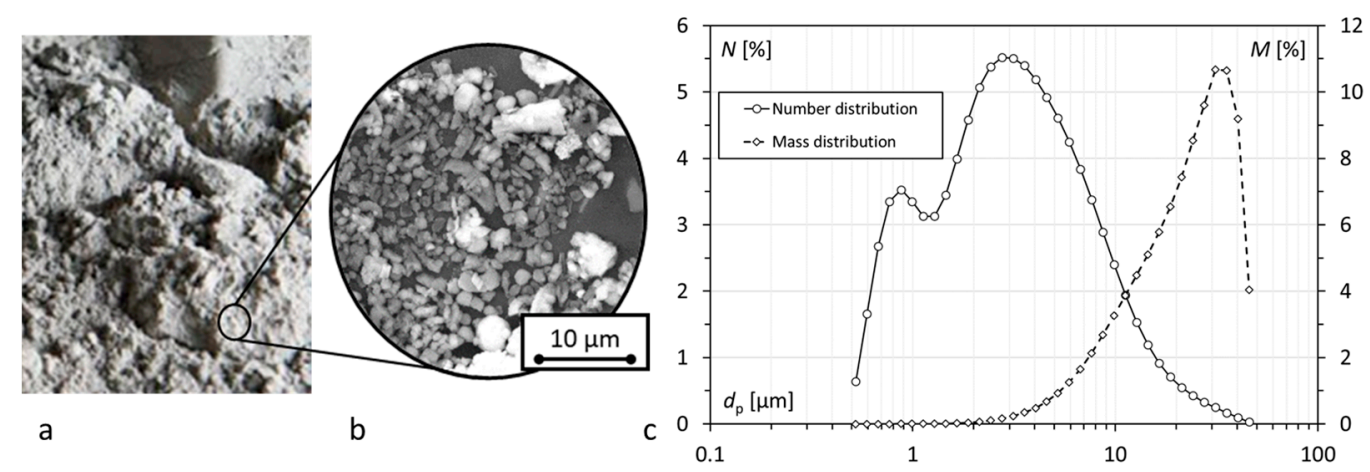

Figure 1. (a) Digital and (b) SEI-SEM images of the powder in the as-received condition, (c) number, N, and mass distributions, $\mathrm{M}$, of the raw meal powder.

The feeding system is comprised of two different systems to guarantee the constant dosing rate and the breaking process of the agglomerates. The first part is composed of a hopper, equipped with a calibrated screw able to dosing the powder in the reservoir connect to a Venturi nozzle. The Venturi nozzle is operated by dried and cleaned shop air in order to suck the powder from the secondary line connected to the throat section. By the shear force, the Venturi nozzle allows the breakup of the agglomerates $[40,41]$ ensuring the repeatability of the erosion tests. After the Venturi, a cylindrical nozzle with an internal diameter of $4 \mathrm{~mm}$ and a length equal to $32 \mathrm{~mm}$ was mounted. The sample overlook the nozzle at a fixed distance equal to $10 \mathrm{~mm}$ according to the standard, as reported in Figure $2 \mathrm{a}$ and it is held by a sliding and tiltable table to adjust the relative angle between nozzle and specimen surface 
as reported in Figure $2 \mathrm{~b}$. Samples with dimensions of $50 \mathrm{~mm} \times 25 \mathrm{~mm} \times 10 \mathrm{~mm}$ were cut (by abrasive water-jet process) from the wear plate and their top surface was ground, polished (mirror-like finishing up to $1 \mu \mathrm{m}$ diamond paste), and ultrasonically cleaned in acetone. The erosion test used a constant powder-feeding rate $(10 \mathrm{~g} / \mathrm{min})$, impingement angle $\left(90^{\circ}\right)$, and particle impact velocity $(100 \mathrm{~m} / \mathrm{s})$.
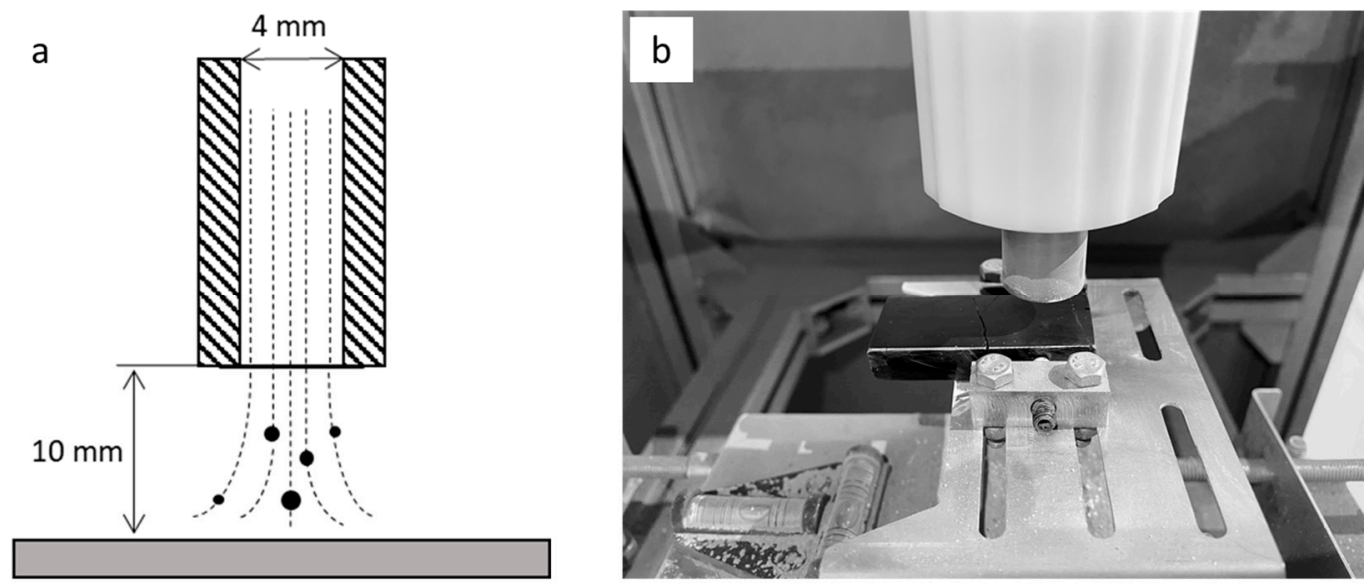

Figure 2. (a) Sample and nozzle setup, (b) image of the erosion sample on the sliding and tiltable table.

Three different erosion times, i.e., $30 \mathrm{~min}, 60 \mathrm{~min}$, and $90 \mathrm{~min}$, were investigated. For each condition, five samples were tested. After each erosion test, the sample was ultrasonically cleaned in acetone to remove any traces of the erodent powder. The erosion resistance was evaluated from the mass loss, computed by weighing each specimen before and after the erosion test. A Kern ABT 100-5NM (Kern, Balingen, Germany) analytical balance, with an accuracy resolution of $0.01 \mathrm{mg}$ was used.

The worn surfaces were then analyzed by both optical and scanning electron microscopy in an attempt to provide a better understanding of the mechanisms of material removal. The investigations were conducted on the worn top surface and the crosssectioned surface. The latter was cut in the center of the erosion crater and polished using the above-described standard metallographic technique.

By using an LTF (Lenton Furnaces and Ovens, Hope, UK) tube furnace, the effects of a destabilization heat treatment on the resulting microstructure and, in turn, on the erosion behavior, were evaluated. Similar to the erosion times investigated in the as-received condition, i.e., $30 \mathrm{~min}, 60 \mathrm{~min}$, and $90 \mathrm{~min}$, also for the heat-treated condition five samples were tested at the same erosion times. To this end, the furnace was heated at $20^{\circ} \mathrm{C} / \mathrm{min}$ up to $950{ }^{\circ} \mathrm{C}$, and then the samples were held at this temperature for $3 \mathrm{~h}$ to promote the destabilization of the austenite phase. The final oil quenching to room temperature enabled to precipitate a fine dispersion of the carbides within the matrix. The overall bulk hardness of the hardfacing, before and after the heat treatment, was evaluated under $30 \mathrm{~kg}$ load and $15 \mathrm{~s}$ loading time (HV30) by VH Metkon (Metkon Instruments Inc., Bursa, Turkey) Vickers hardness tester. The hardness of the welded layer was determined as the average of five indentations to check the reproducibility of the hardness data. Then, both microstructural investigations and erosion tests were carried out according to the above-described methods. Microstructural (OM, SEM/EDS) and crystallographic (XRD) investigations were performed on the heat-treated samples to evaluate the relationship between microstructural features and erosion resistance.

\section{Results and Discussion}

\subsection{Microstructural Investigations of the As-Received HCCI}

Figure 3 a displays a digital image of the resistant side of the wear plate in the asreceived condition from which the bead pattern, i.e., juxtaposed passes with continuous 
overlap, enables to counteract severe wear conditions. Moreover, stress relief cracks, resulting from the relaxation of heat stress in the deposit, develop at right angles to the weld beads and are regularly spaced. To ensure the wear resistance of the hardfacing, these cracks must not be spread to the base metal. Figure $3 \mathrm{~b}$ shows the 3D isometric optical micrographs of the wear plate in the hardfacing/substrate interface. As can be seen from the cross-section, the crack does not reach the steel substrate, thanks to the buffer layer (the light gray band between the hardfacing and the steel) that acts as a barrier to cracking.

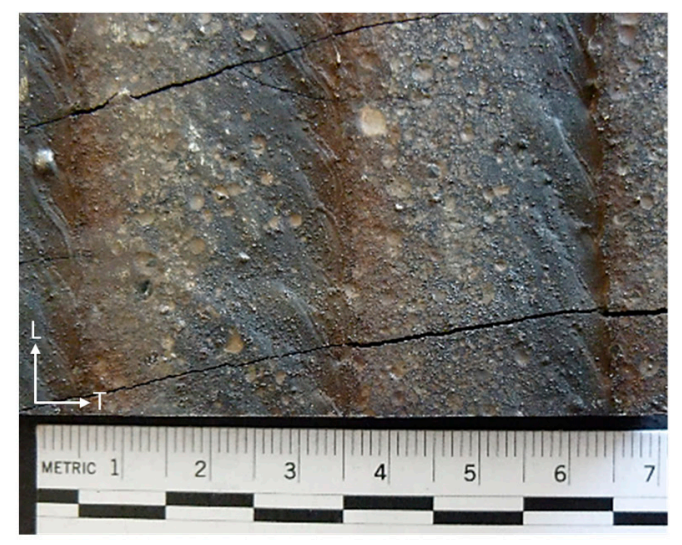

a

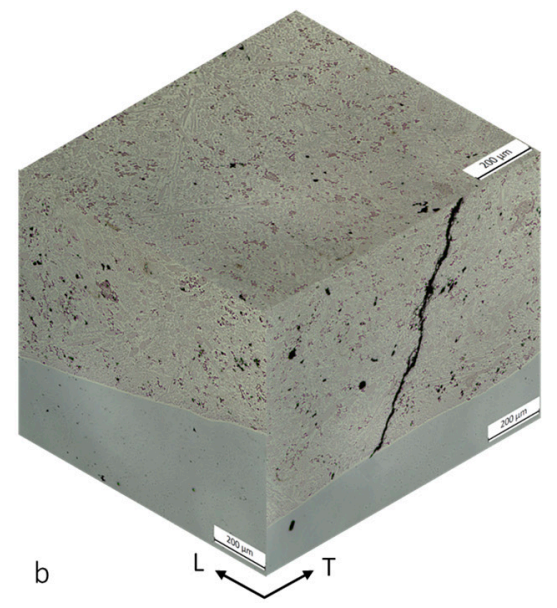

Figure 3. Hardfacing plate: (a) image of the resistant side of the wear plate; (b) 3D isometric optical micrographs of the unetched Fe-Cr-C alloy.

X-ray diffraction pattern of the deposit on the resistant-side layer is shown in Figure 4: the presence of $\mathrm{MC}(\mathrm{M}=\mathrm{Nb}, \mathrm{Mo}), \mathrm{M}_{7} \mathrm{C}_{3}(\mathrm{M}=\mathrm{Cr}, \mathrm{Fe})$, and austenite phases can be detected. Per the liquidus projection of the iron corner of the $\mathrm{Fe}-\mathrm{Cr}-\mathrm{C}$ ternary system $[42,43]$ and according to the evaluated chemical composition (Table 1), the present alloy hardface deposit falls in the hypereutectic range. Considering the presence of $\mathrm{Nb}$ in the alloy, the formation of $\mathrm{MC}(\mathrm{M}=\mathrm{Nb})$ carbides precedes the formation of proeuctectic $\mathrm{M}_{7} \mathrm{C}_{3}$ carbides [44-46]. $\mathrm{MC}$ carbides precipitate at a high temperature in the melt before the formation of proeutectic $\mathrm{M}_{7} \mathrm{C}_{3}$ carbides, acting as heterogeneous nucleation sites and increasing the nucleation rate promoting the formation of finer proeutectic $\mathrm{M}_{7} \mathrm{C}_{3}$ carbides [44]. As the molten temperature falls to the eutectic point, the residual melt rejects the $\mathrm{Cr}$ and $\mathrm{C}$ atoms: when the $\mathrm{Cr}$ and $\mathrm{C}$ concentrations reach the eutectic composition, the $\left(\gamma+\mathrm{M}_{7} \mathrm{C}_{3}\right)$ eutectic colonies form [44].

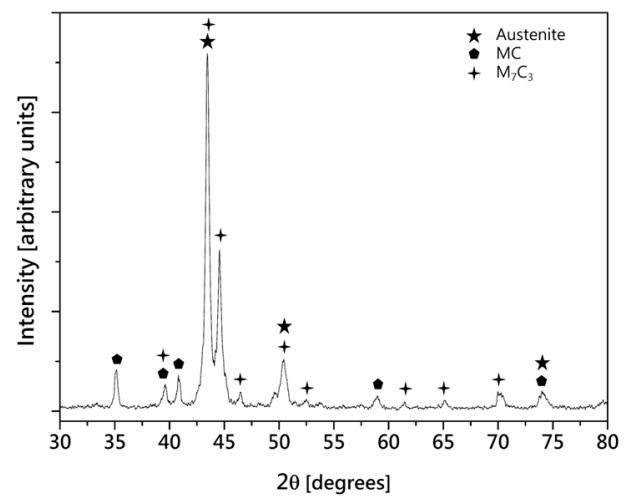

Figure 4. X-ray Diffraction (XRD) patterns of the hardfacing on the resistant-side layer.

The microstructure of the hardfacing, obtained from the polished and etched crosssection samples, is reported in Figure 5. Figure 5a shows the optical micrograph of the T-section of the alloy on the resistant side: in the upper part, i.e., close to the surface, the 
hardfacing presents blade-like proeutectic $\mathrm{M}_{7} \mathrm{C}_{3}$ carbides, with the longer axis perpendicular to the surface and whose orientation is related to the heat flow [47], and the $\left(\gamma+\mathrm{M}_{7} \mathrm{C}_{3}\right)$ eutectic mixture.

With the increase of the distance from the resistant side, the carbides become finer, rod-like, and uniformly distributed throughout the matrix. The red arrows in Figure 5a highlight the stress-relief crack propagation path. SEM investigations were also conducted on the T cross-section of the hardfacing, at about half of the hardfacing thickness, and at the boundary between two welding passes. As revealed in the BSE-SEM image of Figure $5 b$, the different microstructure of the two passes, with coarser primary carbides on the left side of the micrograph and finer ones on the right side, is detectable. The dash-dot yellow line separates the passes with coarser and finer rod-like carbides. The optical micrographs of Figure 5c,d compare the microstructure of the SS (Figure $5 c$ ) and the RS (Figure 5d) regions of the L-section. Both reveal the presence of $\gamma$ dendrites (highlighted by red arrows) adjacent to the proeutectic $\mathrm{M}_{7} \mathrm{C}_{3}$ carbides, whose content is greater in the RS region (Figure $5 \mathrm{~d}$ ). This finding has also been recently reported and described in [44]. Moreover, the effect of the solidification conditions is detectable: near the surface, the higher thermal gradient results in primary blade-like $\mathrm{M}_{7} \mathrm{C}_{3}$ carbides that grow along the preferential growth axis [47]. In addition to the high magnification optical micrographs of Figure 5c,d, BSE-SEM analyses were conducted to highlight the microstructural constituents through compositional contrast imaging. Hence, Figure 5e displays the BSE-SEM micrograph of the T-cross section, which provides an overview of the microstructure, while the high magnification micrograph of Figure $5 \mathrm{f}$ points out the eutectic carbides network. Consistent with the XRD results (see Figure 4), the BSE-SEM micrographs of the T-section (Figure $5 \mathrm{e}, \mathrm{f}$ ) reveal a microstructure composed of primary $\mathrm{M}_{7} \mathrm{C}_{3}$ carbides (labeled as 1 ) surrounded by the eutectic $\left(\gamma+\mathrm{M}_{7} \mathrm{C}_{3}\right)$ structure (labeled as 2$)$. The carbides reveal a rhombohedral/hexagonal cross-section [48]. $\mathrm{Nb}$ additions enabled the precipitation of $\mathrm{Nb}$-rich MC carbides displayed as polygonal-shaped structures (labeled as 3), as confirmed by the EDS analyses. $\mathrm{Nb}$ - and Mo-rich carbides (labeled as 4) and Mo- and Fe-rich carbides (labeled as 5) have also been detected. From the high magnification BSE-SEM micrograph of Figure 5f, traces of martensite (labeled as 6) could also be observed at the periphery of the carbides network $[7,49,50]$.

Considering the influence of the CVF on the microstructural and wear characteristics of the hardfacing $[29,31,51]$, quantitative metallographic image analyses were carried out. Figure 6 displays examples of the representative microstructures analyzed to evaluate the CVF parameter: Figure 6a,b show the L-section in the RS and SS, respectively, while Figure $6 c, d$ show the T-section in the RS and SS, respectively.

As seen, the RS presents larger carbides with a plate-like morphology, while the SS presents smaller primary carbides with a polygonal shape. It is worth noting that, even within the same distance from the surface, the microstructure was quite heterogeneous, as the result of the solidification process. The estimated mean CVF values were $26.25 \%$ and $23.45 \%$ for the L-section in the RS and SS, respectively, while $25.98 \%$ and $24.40 \%$ for the $\mathrm{T}$-section in the RS and SS, respectively. Beyond the negligible differences in the number of carbides between L-section and T-section, attempts were made to evaluate the size of the investigated carbides. Hence, Figure 5e displays the Cumulative Distribution Function (CDF) of the carbides' area, A. These distributions reveal that for the L-section (both for the RS, labeled as L_RS, and for the SS, labeled as L_SS) about $90 \%$ of the carbides had an area in the range of 4-60 $\mu \mathrm{m}^{2}$ while for the T-section (both for RS, labeled as T_RS and for the SS, labeled as T_SS) about $90 \%$ of the carbides had an area in the range of $2-40 \mu \mathrm{m}^{2}$. In all cases, carbides with a larger area (from $100 \mu \mathrm{m}^{2}$ up to $900 \mu \mathrm{m}^{2}$ ) were much less with respect to the numerous eutectic carbides, the share of these large carbides amounted to about $10 \%$ of the total. 

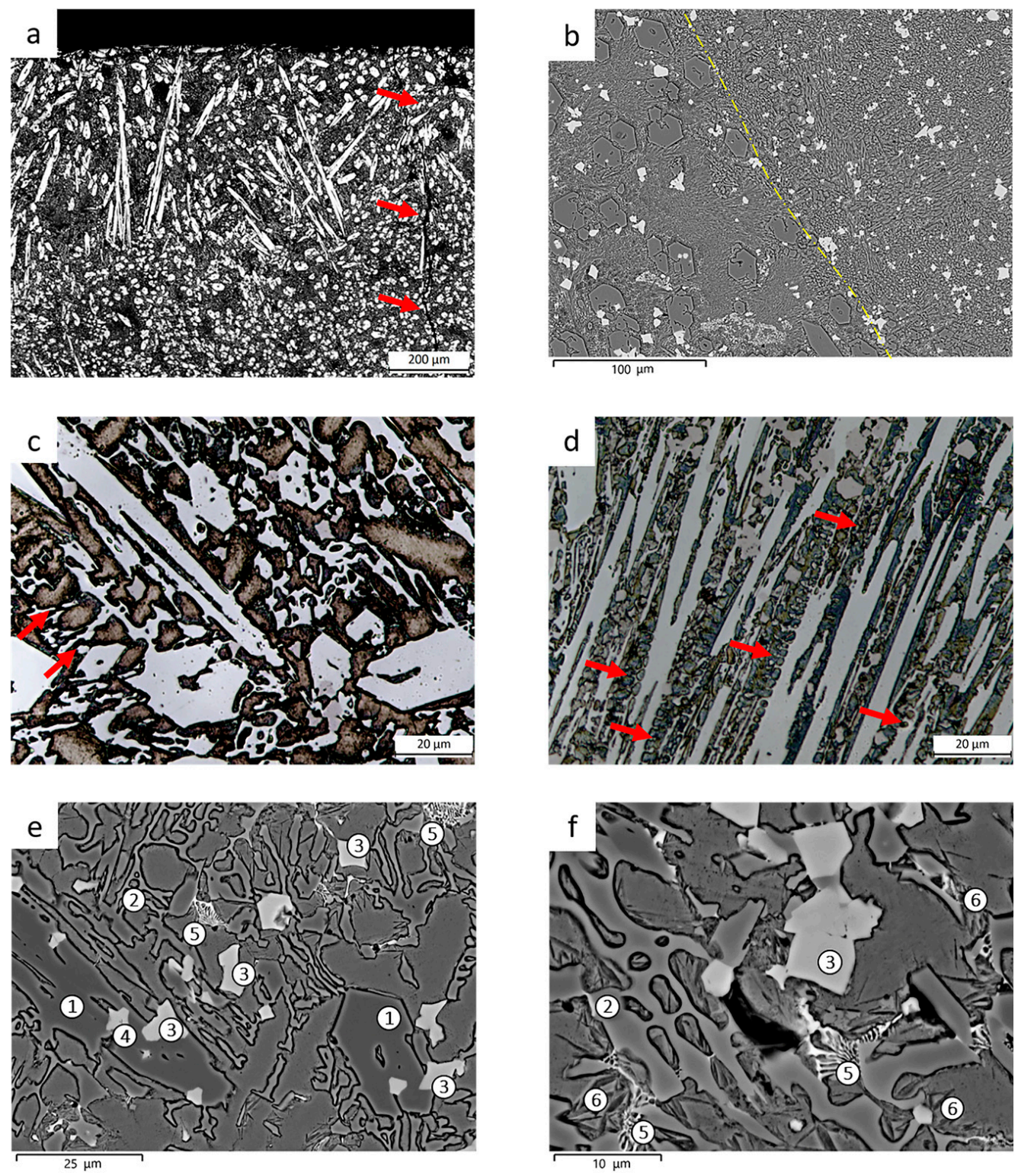

Figure 5. (a) Optical microscope (OM) micrograph of the T-section of the hardfacing captured from the resistant side, red arrows highlight the crack propagation path; (b) BSE-SEM image of the Tsection at the boundary between two welding passes: the dash-dot yellow line separates the passes with coarser and finer rod-like carbides; (c,d) OM micrographs of the L-section in the substrate and resistant side, respectively; (e,f) BSE-SEM images of the T-section whit primary $\mathrm{M}_{7} \mathrm{C}_{3}$ carbides (labeled as 1), eutectic $\left(\gamma+\mathrm{M}_{7} \mathrm{C}_{3}\right)$ structure (labeled as 2), Nb-rich MC carbides (labeled as 3), $\mathrm{Nb}$ and Mo-rich carbides (labeled as 4), Mo- and Fe-rich carbides (labeled as 5) and traces of martensite (labeled as 6). 

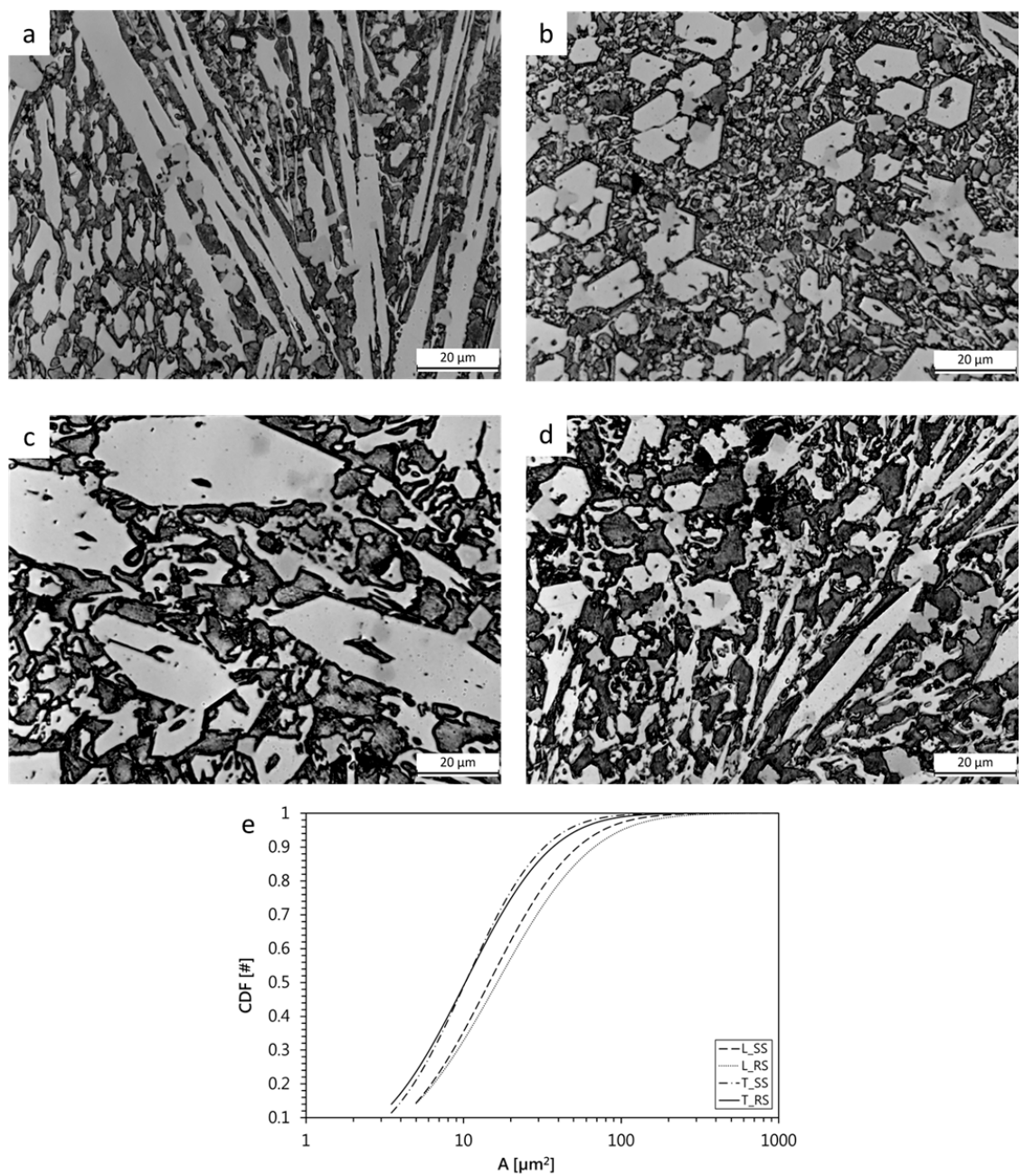

Figure 6. Representative OM micrographs used for the carbide volume fraction (\% CVF) evaluation: L-section in the RS (a) and SS (b); T-section in the resistant side (RS) (c) and substrate side (SS) (d). (e) The cumulative distribution function (CDF) of the carbides' area A at different locations.

\subsection{Hardness of the As-Received HCCI}

The results of hardness measurements, taken on the $\mathrm{T}$ cross-section, are reported in Figure 7. Figure 7a shows the Vickers hardness profile measured at increasing distances of 1 $\mathrm{mm}$ from the top of the welded hardfacing up to the bottom of the steel substrate. Moreover, the hardness of both the matrix and the primary carbides was evaluated (Figure 7b).

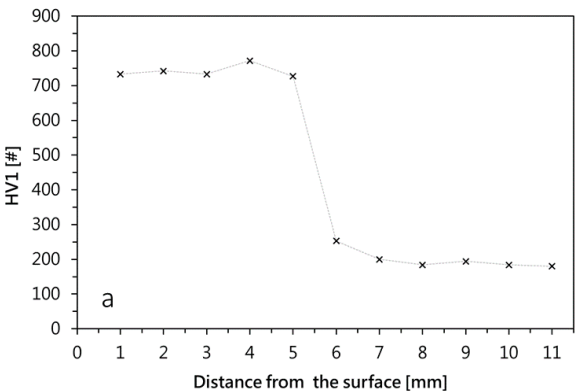

(a)

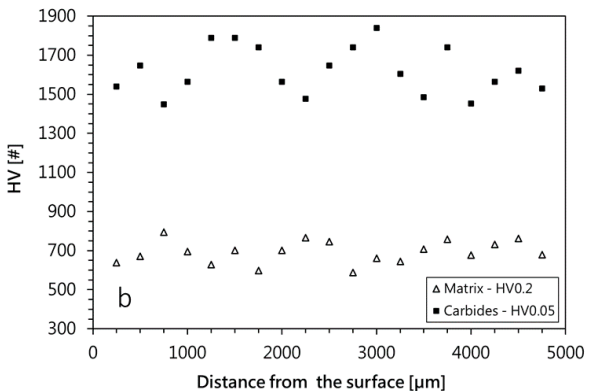

(b)

Figure 7. Vickers hardness measurements on the T cross-section: (a) hardness profile across the hardfacing plate from the resistant side up to the steel substrate; (b) microhardness values across the hardfacing for matrix and Cr-based carbides. 


\subsection{Effect of the Heat Treatment on Microstructure and Erosion Behavior}

The erosive resistance of the investigated HCCI was evaluated by erosion tests conducted by comparing the behavior of the alloy in the as-received and heat-treated conditions. Consecutive tests at $30 \mathrm{~min}, 60 \mathrm{~min}$, and $90 \mathrm{~min}$ of erosion were conducted.

Figure 8 represents the BSE-SEM microstructures of the as-received and heat-treated samples, together with the respective XRD spectra. In the as-received state, the high magnification BSE-SEM micrograph (Figure 8a) displays a microstructure mainly consisted of $\mathrm{M}_{7} \mathrm{C}_{3}$ eutectic carbides, traces of martensite, and $\mathrm{MC}$ carbides, in accordance with the identified phases in the respective XRD spectrum (Figure 8c). In the heat-treated condition, the austenite is transformed into martensite, as revealed by the BSE-SEM micrograph (Figure 8 b) and by the martensite peak in the XRD spectrum (Figure 8c).
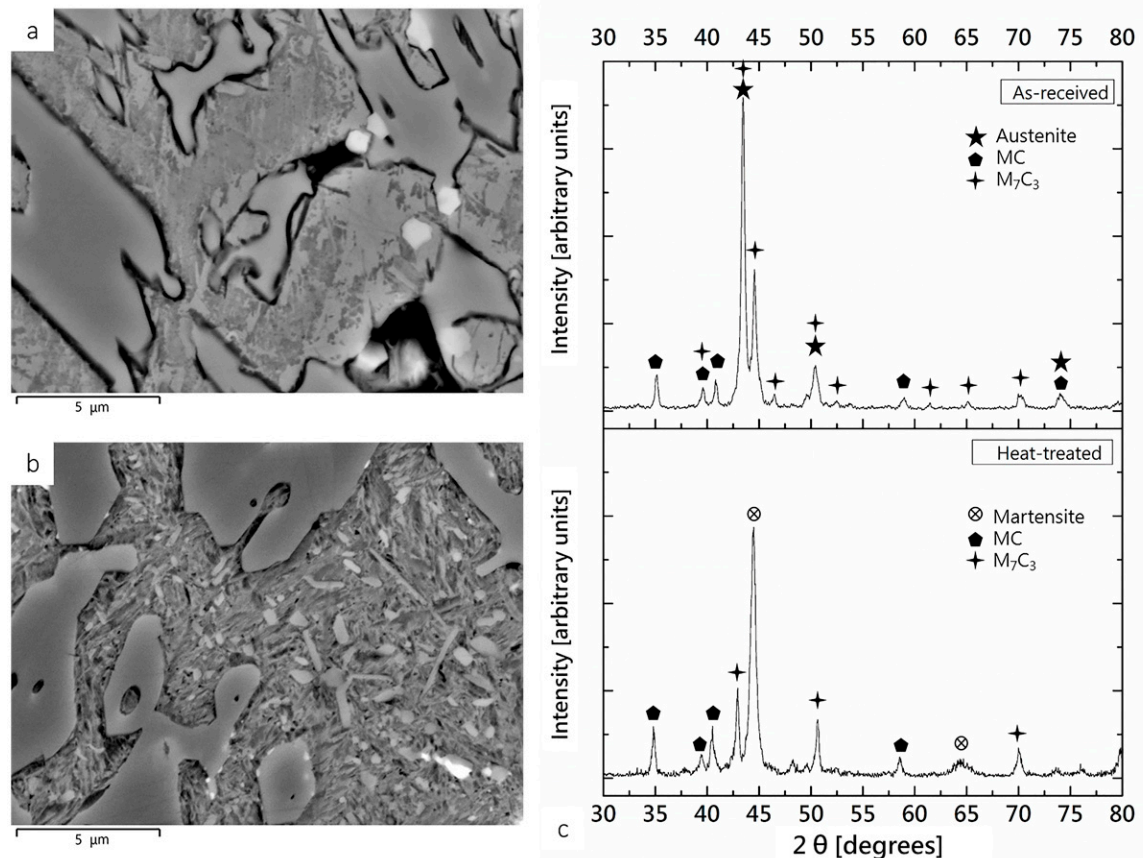

Figure 8. Comparison between as-received and heat-treated conditions. (a,b) BSE-SEM images of the hardfacing microstructure: (a) as-received and (b) heat-treated at $950{ }^{\circ} \mathrm{C}$ for $3 \mathrm{~h}$ and oil quenched. (c) XRD spectra of the as-received and heat-treated conditions.

After destabilization, the secondary carbides precipitated during the heat treatment appear as fine granular particles distributed in the matrix (Figure 8b) [52]. These carbides are detectable from the BSE-SEM images resulting from the deep-etched samples. Figure 9 reports the comparison between the microstructure of the as-received and the heat-treated samples after etching for $24 \mathrm{~h}$ in a solution of $10 \% \mathrm{HCl}$ in methanol, as suggested by [7]. From the BSE-SEM image of Figure $9 b$, the small and uniformly distributed secondary carbides are detectable, in the framework of the matrix structure.

Accordingly, the overall bulk hardness is increased by the thermal treatment: the as-received sample shows $793 \pm 35 \mathrm{HV} 30$ while the heat-treated sample results in $950 \pm 52$ HV30. Figure 10 exhibits the appearance of a representative worn top surface of an erosion crater on the as-received sample. From the digital image (Figure 10a) it can be seen the modification of the substrate surface due to the particle impact. The erosion pattern is characterized by a circular spot with two concentric regions (commonly known as a crater). The internal matt-grey region (with a diameter equal to about $5 \mathrm{~mm}$ ) overlooks the nozzle: in this region, particles impact the substrate for the first time at $90^{\circ}$ with the nominal velocity determining the greater erosion damage. The external circular light-grey region (with a diameter equal to about $9 \mathrm{~mm}$ ) is generated by the secondary impacts characterized by lower impact angle (almost tangential impact) and lower impact velocity. Hence, the 
analyzed eroded area of the worn top surface of the sample, as depicted in the BSE-SEM image of Figure 10b, was a circle of about $3 \mathrm{~mm}$ diameter in the central region of the erosion crater.
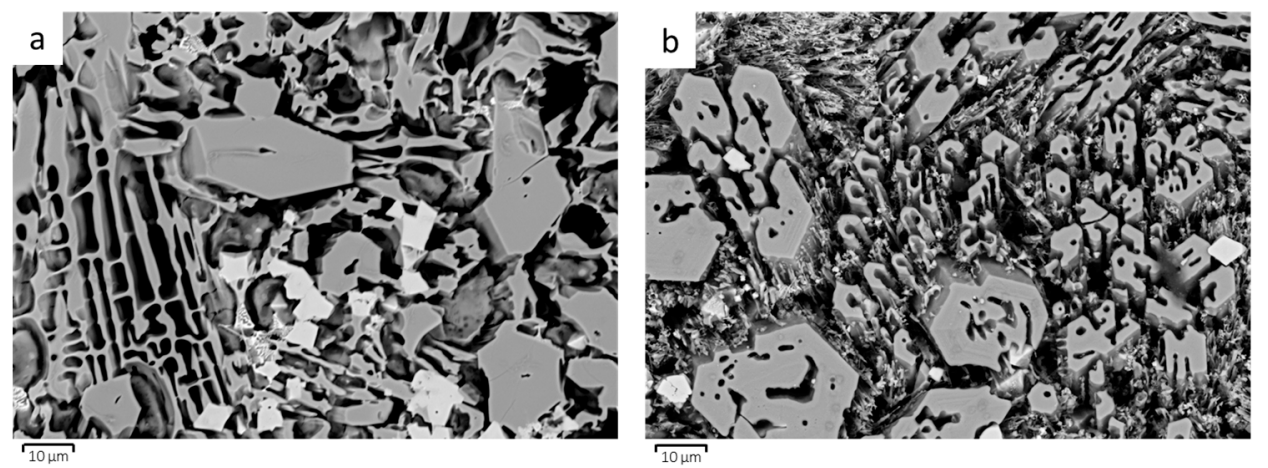

Figure 9. Deep-etched BSE-SEM images of (a) as-received and (b) heat-treated samples.
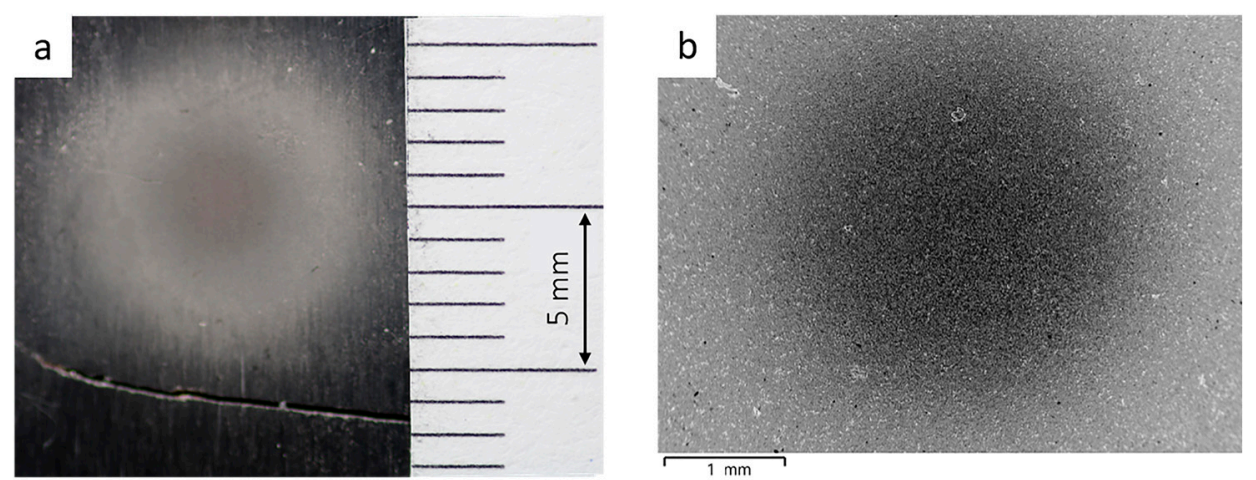

Figure 10. Images of the top surface after erosion: (a) digital image; (b) BSE-SEM image.

The worn surface was analyzed through SEM observation of the top surface after the erosion process. As depicted in Figure 11, which displays the worn surface of an erosion crater on the as-received sample after $30 \mathrm{~min}$ of erosion, SEM images revealed both the topography of the worn surface (Figure 11a) and the distribution of the chemical elements, detected by the X-ray elemental maps (Figure 11b,c). Due to the erosion, the surface appears rough, with the $\mathrm{Cr}$-rich carbides protrusions resulting from the selective wear of the matrix [31].

Previous research has established the tricky phenomena associated with the wear behavior of HCCIs, deeply investigating the role of matrix, primary and eutectic carbides on the wear resistance [31]. The cross-section of the erosion crater, in the as-received condition, was thus investigated by SEM: Figure 12 depicts the comparison between $30 \mathrm{~min}$ and $60 \mathrm{~min}$ of erosion of two different regions of the same sample. As can be seen, the cross-section analysis in the center of the erosion crater does not provide information about the erosion mechanisms that occurred. Time-wise evolution of the erosion and wear phenomena are not detectable only by the cross-section evaluation. After $30 \mathrm{~min}$ of erosion, Figure $12 a$, primary $\mathrm{M}_{7} \mathrm{C}_{3}$ carbides appear emerging from the surrounding matrix, which results in some damage by the erodent particles. Conversely, after 60 min of erosion, the center of the erosion crater appears uniformly eroded, with no evident carbide protrusions (Figure 12b). Such behaviors rely on the mutual interdependence between microstructural features, of both matrix and carbides (i.e., size, volume fraction, distribution of primary carbide and eutectic carbides), and fracture behavior (i.e., fracture toughness and hardness). It has been reported [31] that hard primary carbides near the surface could be spalled off as they are cracked during the wear process, despite the high hardness. At the same time, the microstructure, mainly composed of eutectic carbides that show a lower hardness because 
of the decrease of the volume fraction of the $\mathrm{M}_{7} \mathrm{C}_{3}$, reveals a better wear resistance thanks to the uniform distribution of such carbides. Such harder and uniformly distributed carbides ensure an increased wear resistance since abrasives cannot effectively penetrate into the matrix and carbides are not easily separate from it [53,54]. According to the literature, relatively homogeneous wear is observed (Figure 12b).

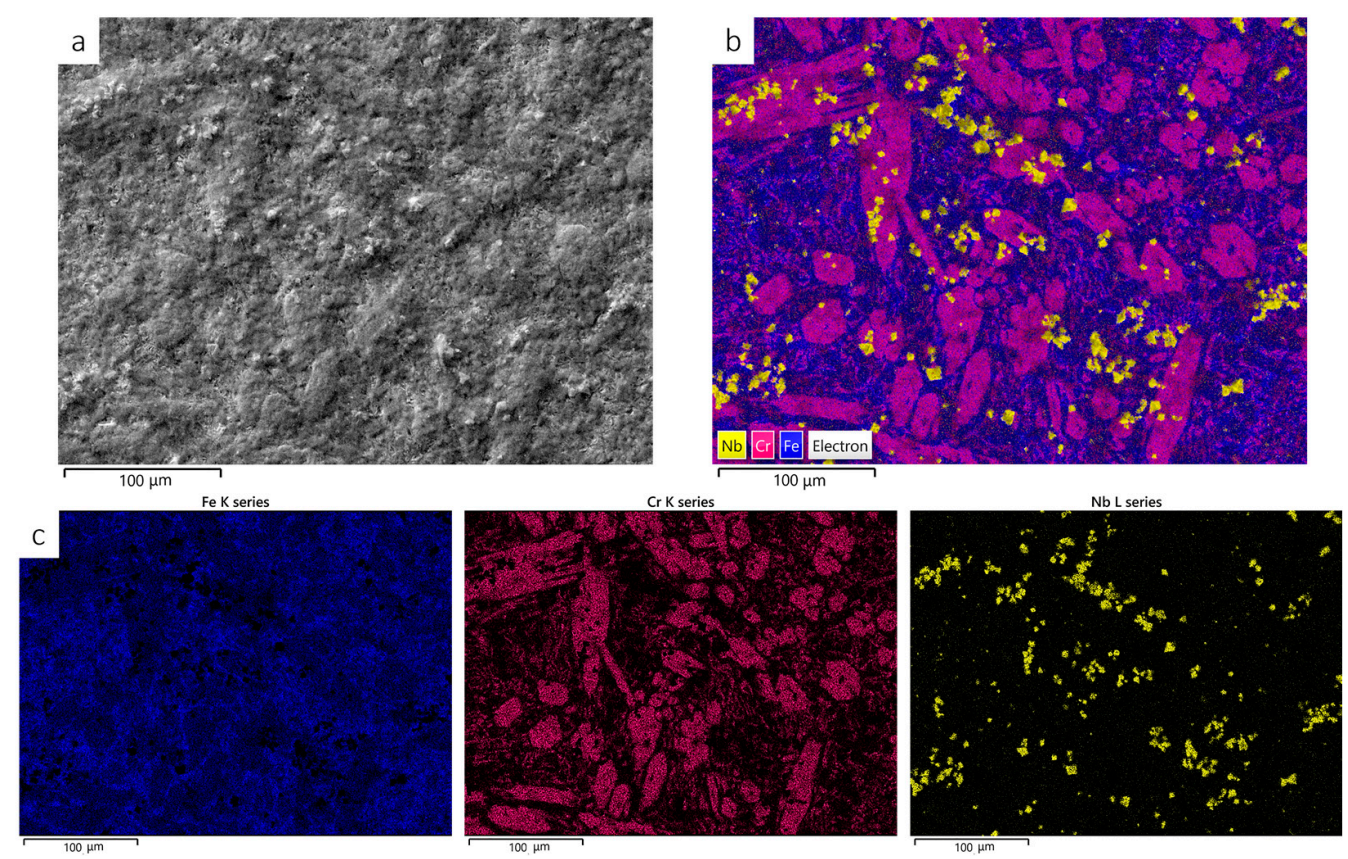

Figure 11. SEM images of the worn surface, center of the crater after $30 \mathrm{~min}$ of erosion on an asreceived sample: (a) SEI-SEM image, (b) layered image of X-ray maps, and (c) maps of the elemental distribution.
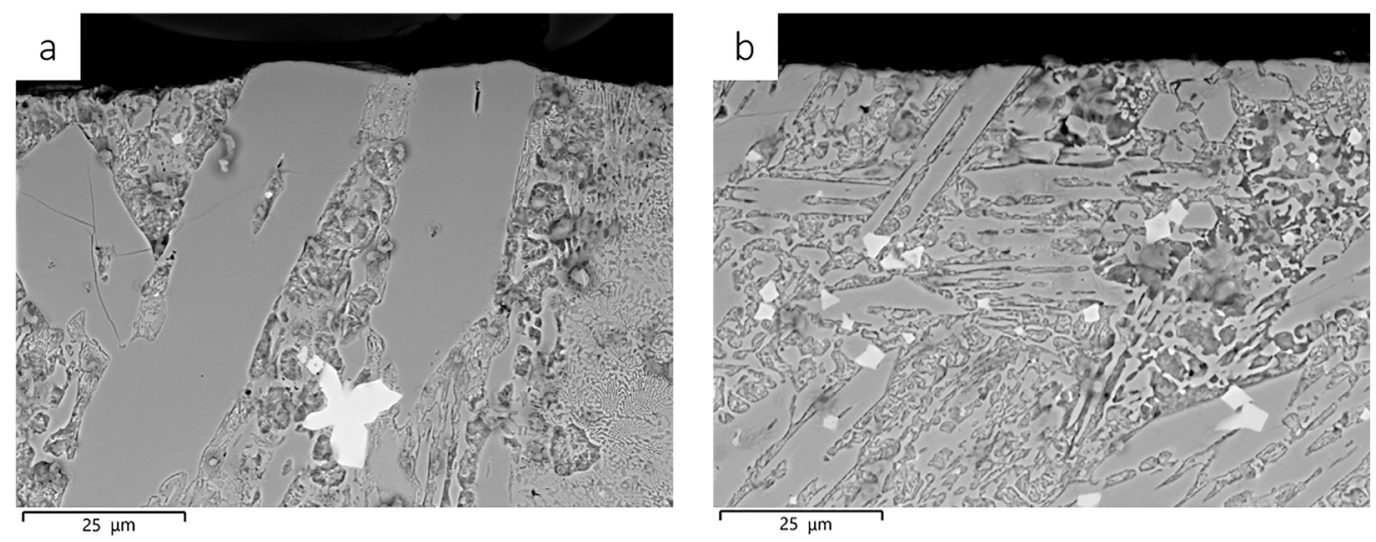

Figure 12. BSE-SEM micrographs of the cross-sectioned erosion crater: (a) 30 min of erosion, (b) 60 min of erosion.

In the light of the above reported microstructural findings, to exclude the influence of the microstructural changes associated with the chemical and solidification conditions, erosion tests were performed on the same area of the sample. The erosion results are reported in Figure 13, as the weight loss against the exposure time: it follows that the wear behavior of the heat-treated samples toward erosion is better than the as-received ones. Regardless of the condition, the weight loss by the sample increases with the erosion time with a slightly lower slope for the heat-treated sample. It is worth noting the weight loss decrease for the heat-treated condition, promoted by the destabilization treatment and, in turn, by the superior erosion resistance of the obtained microstructure. Conversely, the weight loss of the as-received sample increases linearly with erosion time. Note that the 
uncertainty band associated with the weight loss measurements has the same size as the markers on the charts (extended uncertainty is $\pm 0.06 \mathrm{mg}$ ).

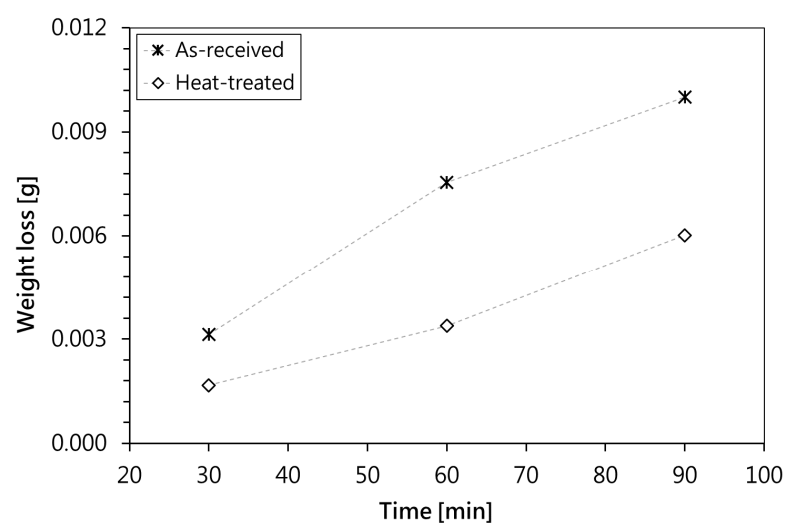

Figure 13. Erosion tests result for the as-received and heat-treated hardfacing samples: weight loss against erosion time.

The microstructural investigations were performed on the top worn surfaces by both OM to evaluate the CVF, and by SEM to study the topographical changes associated with the erosion phenomena. Since the morphologies of carbides, together with the microstructure of the matrix, are the predominant characteristics influencing the hardness and wear behavior of the alloy, it is of high relevance to consider their quantitative analysis. Table 2 summarizes the CVF values and the respective standard deviations in parentheses for the as-received and the heat-treated conditions.

Table 2. CVF values and respective standard deviations (in parenthesis) in the as-received and heat-treated conditions with respect to erosion time. The initial condition before the erosion test is $0 \mathrm{~min}$.

\begin{tabular}{ccccc}
\hline & \multicolumn{5}{c}{ CVF } \\
\cline { 2 - 5 } Conditions & \multicolumn{4}{c}{ Erosion Exposure [min] } \\
\cline { 2 - 5 } & $\mathbf{0}$ & $\mathbf{3 0}$ & $\mathbf{6 0}$ & $\mathbf{9 0}$ \\
\hline As-received & $22.19(1.31)$ & $11.54(2.34)$ & $9.92(2.41)$ & $10.24(3.99)$ \\
\hline Heat-treated & $28.84(0.76)$ & $12.54(1.95)$ & $14.74(2.71)$ & $13.86(2.29)$ \\
\hline
\end{tabular}

As for the initial condition, indicated as $0 \mathrm{~min}$, it can be stated that for the as-received and the heat-treated samples the CVF values are comparable. Conversely, from the comparison between the CVF values in the initial condition and after $30 \mathrm{~min}, 60 \mathrm{~min}$, and $90 \mathrm{~min}$ of erosion it appears that, aside from the condition, the CVF is reduced to half its initial value and it seems not significantly affected by the erosion time. These experimental findings shed light on the time-wise evolution of weight loss (see Figure 13).

To further investigate the efficacy of the heat treatment, SEM analyses of the worn top surfaces were conducted. Figure 14 presents the topography in the center of the crater after erosion through both SEI-SEM and BSE-SEM images.

From the comparison between the worn surfaces of the as-received (Figure 14a,b) and the heat-treated (Figure 14c,d) samples after 30 min of erosion, it can be detected the different wear behavior. The surface of the as-received sample shows wide carbide protrusion resulting from the selective wear of the matrix while the heat-treated sample reveals the simultaneous wear of matrix and carbides. Indeed, the reduced hardness difference between matrix and carbides in the heat-treated sample, $850 \pm 52 \mathrm{HV} 0.2$, and $1620 \pm 122$ HV0.05 respectively, compared with the as-received sample, $692 \pm 58$ HV0.2 and $1477 \pm 147 \mathrm{HV} 0.05$ respectively, increases the wear resistance of the alloy. 

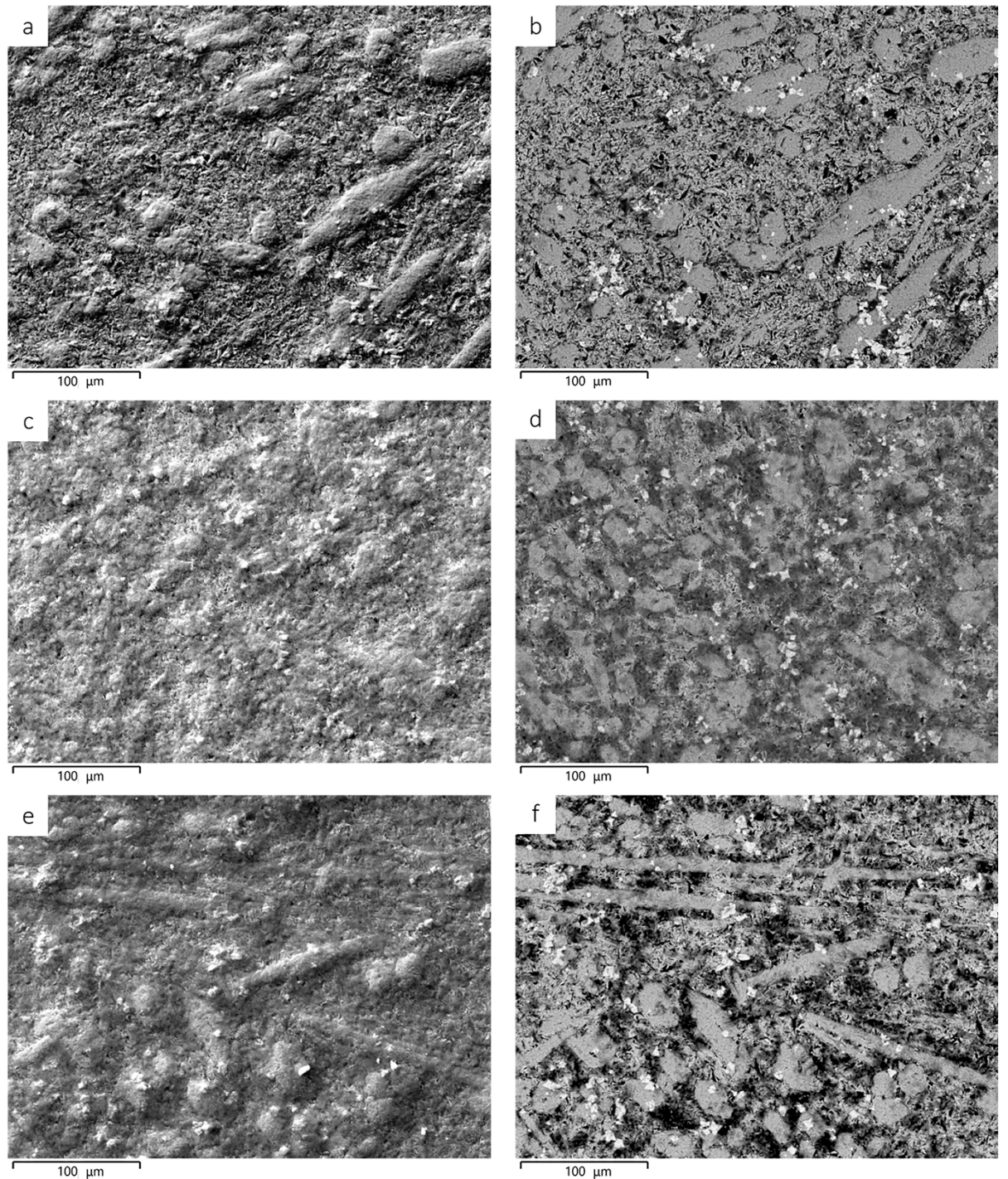

Figure 14. SEI-BSE images of the center of the crater: $(\mathbf{a}, \mathbf{b})$ SEI-BSE images of the as-received hardfacing after $30 \mathrm{~min}$ of erosion; (c,d) SEI-BSE images of the heat-treated hardfacing after $30 \mathrm{~min}$ of erosion; (e,f) SEI-BSE images of the heat-treated hardfacing after $60 \mathrm{~min}$ of erosion.

The improved wear resistance of the heat-treated sample is further confirmed by the surface topography appearance after $60 \mathrm{~min}$ of erosion (Figure 14e,f), which is somewhat similar to the condition of the as-received sample after $30 \mathrm{~min}$ of erosion (Figure 14a,b). Note that the weight loss of these two samples is nearly the same. In the light of that, it can be inferred the increased capability of the higher hardness matrix in providing better support for the carbides, compared with the austenitic one, in agreement with findings in [52].

These findings suggest that the proposed heat treatment is effective in improving the erosion resistance of the investigated HCCI alloy, which is strongly affected by the matrix/carbides hardness difference.

\section{Conclusions}

The microstructural characteristics and the erosive wear behavior of a hypereutectic HCCI hardfacing alloy were experimentally investigated by considering the effect of a destabilization heat treatment. The experimental findings indicate that:

- $\quad$ according to microstructural and X-ray diffraction analyses, the investigated HCCI consists of a mixture of $\mathrm{MC}$ and $\mathrm{M}_{7} \mathrm{C}_{3}$ carbides dispersed in a metastable austenite 
matrix containing a high $\mathrm{Cr}$ concentration, with traces of martensite at the carbides' periphery. $\mathrm{Nb}$-rich and Mo-rich carbides were also detected;

- the considered destabilization treatment $\left(950^{\circ} \mathrm{C}\right.$ for $3 \mathrm{~h}+$ oil quenching) promotes the austenite to martensite phase transformation and the precipitation of secondary carbides;

- the erosion tests, performed at $30 \mathrm{~min}, 60 \mathrm{~min}$, and $90 \mathrm{~min}$, proved the efficacy of the heat treatment in improving the erosion resistance of the as-received alloy;

- the reduced hardness difference between matrix and carbides in the heat-treated sample has a pivotal role in increasing the wear resistance of the hardfacing.

With the objective of providing a better understanding of the microstructure-property relationships concerning the erosive wear resistance of a $\mathrm{Fe}-\mathrm{Cr}-\mathrm{C}$ hardfacing alloy, the experimental findings of this study give some remarkable hints, useful for optimized exploitation of HCCIs in heavy-duty applications. The key takeaways of the research improve the knowledge of the erosive behavior of hardfacing alloy due to the impact of micro-sized particles and would thus reflect towards the increase of their performance and, in turn, of their application ranges.

Author Contributions: Conceptualization, A.F. and A.S.; Data curation, A.V.; Investigation, A.V.; Methodology, A.F. and A.S.; Supervision, M.M. and M.P.; Writing—original draft, A.F.; Writingreview \& editing, A.S. and M.M. All authors have read and agreed to the published version of the manuscript.

Funding: This research received no external funding.

Institutional Review Board Statement: Not applicable.

Informed Consent Statement: Not applicable.

Data Availability Statement: Not applicable.

Acknowledgments: The authors owe thanks to Eng. Paolo Saccenti of Boldrocchi S.r.l. (Biassono, Monza-Brianza, Italy) for the technical support in this research. The authors wish to gratefully acknowledge Luca Marchetti and Matteo Seno for their support in the experimental campaign. Thanks are also due to Iuri Boromei for his contribution to the GD-OES analyses.

Conflicts of Interest: The authors declare no conflict of interest.

\section{References}

1. Venkatesh, B.; Sriker, K.; Prabhakar, V.S.V. Wear Characteristics of Hardfacing Alloys: State-of-the-art. Procedia Mater. Sci. 2015, 10, 527-532. [CrossRef]

2. Jain, A.-S.; Chang, H.; Tang, X.; Hinckley, B.; Zhang, M.-X. Refinement of primary carbides in hypereutectic high-chromium cast irons: A review. J. Mater. Sci. 2021, 56, 999-1038. [CrossRef]

3. Jia, R.; Liu, S.; Luo, Z.; Ning, J.; Wang, H.; Luo, T.; Zhu, Y.; Yuan, X.; Wang, Z. Microstructure and wear resistance of WC and high chromium cast iron hardfacing layers. Coatings 2020, 10, 852. [CrossRef]

4. Buytoz, S. Microstructural properties of $\mathrm{M}_{7} \mathrm{C}_{3}$ eutectic carbides in a Fe-Cr-C alloy. Mater. Lett. 2006, 60, 605-608. [CrossRef]

5. Fan, C.; Chen, M.-C.; Chang, C.-M.; Wu, W. Microstructure change caused by $(\mathrm{Cr}, \mathrm{Fe}){ }_{23} \mathrm{C}_{6}$ carbides in high chromium Fe-Cr-C hardfacing alloys. Surf. Coat. Technol. 2006, 201, 908-912. [CrossRef]

6. Lin, C.-M.; Chang, C.-M.; Chen, J.-H.; Hsieh, C.-C.; Wu, W. Microstructural evolution of hypoeutectic, near-eutectic, and hypereutectic high-carbon Cr-based hard-facing alloys. Metall. Mater. Trans. A 2009, 40, 1031-1038. [CrossRef]

7. Nayak, U.P.; Guitar, M.A.; Mücklich, F. A comparative study on the influence of chromium on the phase fraction and elemental distribution in as-cast high chromium cast irons: Simulation vs. experimentation. Metals 2019, 10, 30. [CrossRef]

8. Zhi, X.; Xing, J.; Gao, Y.; Fu, H.; Peng, J.; Xiao, B. Effect of heat treatment on microstructure and mechanical properties of a Ti-bearing hypereutectic high chromium white cast iron. Mater. Sci. Eng. A 2008, 487, 171-179. [CrossRef]

9. Gonzalez-Pociño, A.; Alvarez-Antolin, F.; Asensio-Lozano, J. Optimization of thermal processes applied to hypoeutectic white cast iron containing 25\% Cr aimed at increasing erosive wear resistance. Metals 2020, 10, 359. [CrossRef]

10. Karantzalis, E.; Lekatou, A.; Mavros, H. Microstructure and properties of high chromium cast irons: Effect of heat treatments and alloying additions. Int. J. Cast Met. Res. 2009, 22, 448-456. [CrossRef]

11. Cortés-Carrillo, E.; Bedolla-Jacuinde, A.; Mejía, I.; Zepeda, C.M.; Zuno-Silva, J.; Guerra-Lopez, F.V. Effects of tungsten on the microstructure and on the abrasive wear behavior of a high-chromium white iron. Wear 2017, 376-377, 77-85. [CrossRef]

12. Lv, Y.; Sun, Y.; Zhao, J.; Yu, G.; Shen, J.; Hu, S. Effect of tungsten on microstructure and properties of high chromium cast iron. Mater. Des. 2012, 39, 303-308. [CrossRef] 
13. Radulovic, M.; Fiset, M.; Peev, K.; Tomovic, M. The influence of vanadium on fracture toughness and abrasion resistance in high chromium white cast irons. J. Mater. Sci. 1994, 29, 5085-5094. [CrossRef]

14. Zhi, X.; Xing, J.; Fu, H.; Xiao, B. Effect of niobium on the as-cast microstructure of hypereutectic high chromium cast iron. Mater. Lett. 2008, 62, 857-860. [CrossRef]

15. Filipovic, M.; Kamberovic, Z.; Korac, M.; Gavrilovski, M. Microstructure and mechanical properties of Fe-Cr-C-Nb white cast irons. Mater. Des. 2013, 47, 41-48. [CrossRef]

16. Bedolla-Jacuinde, A.; Correa, R.; Quezada, J.G.; Maldonado, C. Effect of titanium on the as-cast microstructure of a $16 \%$ chromium white iron. Mater. Sci. Eng. A 2005, 398, 297-308. [CrossRef]

17. Scandian, C.; Boher, C.; de Mello, J.D.B.; Rézaï-Aria, F. Effect of molybdenum and chromium contents in sliding wear of high-chromium white cast iron: The relationship between microstructure and wear. Wear 2009, 267, 401-408. [CrossRef]

18. Imurai, S.; Thanachayanont, C.; Pearce, J.T.H.; Tsuda, K.; Chairuangsri, T. Effects of Mo on microstructure of as-cast 28 wt.\% Cr-2.6 wt.\% C-(0-10) wt.\% Mo irons. Mater. Charact. 2014, 90, 99-112. [CrossRef]

19. Chatterjee, S.; Pal, T.K. Weld procedural effect on the performance of iron based hardfacing deposits on cast iron substrate. J. Mater. Process. Technol. 2006, 173, 61-69. [CrossRef]

20. Liu, D.; Liu, R.; Wei, Y. Effects of titanium additive on microstructure and wear performance of iron-based slag-free self-shielded flux-cored wire. Surf. Coat. Technol. 2012, 207, 579-586. [CrossRef]

21. Hou, Q.Y.; He, Y.Z.; Zhang, Q.A.; Gao, J.S. Influence of molybdenum on the microstructure and wear resistance of nickel-based alloy coating obtained by plasma transferred arc process. Mater. Des. 2007, 28, 1982-1987. [CrossRef]

22. Yüksel, N.; Şahin, S. Wear behavior-hardness-microstructure relation of Fe-Cr-C and Fe-Cr-C-B based hardfacing alloys. Mater. Des. 2014, 58, 491-498. [CrossRef]

23. Tang, X.H.; Chung, R.; Li, D.Y.; Hinckley, B.; Dolman, K. Variations in microstructure of high chromium cast irons and resultant changes in resistance to wear, corrosion and corrosive wear. Wear 2009, 267, 116-121. [CrossRef]

24. Gelfi, M.; Pola, A.; Girelli, L.; Zacco, A.; Masotti, M.; La Vecchia, G.M. Effect of heat treatment on microstructure and erosion resistance of white cast irons for slurry pumping applications. Wear 2019, 428-429, 438-448. [CrossRef]

25. Abdel-Aziz, K.; El-Shennawy, M.; Omar, A.A. Microstructural characteristics and mechanical properties of heat treated high-Cr white cast iron alloys. Int. J. Appl. Eng. Res. 2017, 12, 4675-4686.

26. Guitar, M.A.; Suárez, S.; Prat, O.; Duarte Guigou, M.; Gari, V.; Pereira, G.; Mücklich, F. High chromium cast irons: Destabilizedsubcritical secondary carbide precipitation and its effect on hardness and wear properties. J. Mater. Eng. Perform. 2018, 27, 3877-3885. [CrossRef]

27. González, J.; Peral, L.B.; Zafra, A.; Fernández-Pariente, I. Influence of shot peening treatment in erosion wear behavior of high chromium white cast iron. Metals 2019, 9, 933. [CrossRef]

28. Efremenko, V.; Shimizu, K.; Chabak, Y. Effect of destabilizing heat treatment on solid-state phase transformation in high-chromium cast irons. Metall. Mater. Trans. A 2013, 44, 5434-5446. [CrossRef]

29. Sapate, S.; Rama Rao, A. Effect of carbide volume fraction on erosive wear behaviour of hardfacing cast irons. Wear 2004, 256, 774-786. [CrossRef]

30. Sapate, S.G.; RamaRao, A.V. Erosive wear behaviour of weld hardfacing high chromium cast irons: Effect of erodent particles. Tribol. Int. 2006, 39, 206-212. [CrossRef]

31. Kim, C.K.; Lee, S.; Jung, J.-Y. Effects of heat treatment on wear resistance and fracture toughness of duo-cast materials composed of high-chromium white cast iron and low-chromium steel. Metall. Mater. Trans. A 2006, 37, 633-643. [CrossRef]

32. Gasan, H.; Erturk, F. Effects of a destabilization heat treatment on the microstructure and abrasive wear behavior of highchromium white cast iron investigated using different characterization techniques. Metall. Mater. Trans. A 2013, 44, 4993-5005. [CrossRef]

33. Chatterjee, S.; Pal, T.K. Wear behaviour of hardfacing deposits on cast iron. Wear 2003, 255, 417-425. [CrossRef]

34. Gonzalez-Pociño, A.; Alvarez-Antolin, F.; Asensio-Lozano, J. Erosive wear resistance regarding different destabilization heat treatments of austenite in high chromium white cast iron, alloyed with Mo. Metals 2019, 9, 522. [CrossRef]

35. Gonzalez-Pociño, A.; Alvarez-Antolin, F.; Asensio-Lozano, J. Influence of thermal parameters related to destabilization treatments on erosive wear resistance and microstructural variation of white cast iron containing $18 \%$ Cr. Application of Design of Experiments and Rietveld structural analysis. Materials 2019, 12, 3252. [CrossRef]

36. Fordyce, I.; Annasamy, M.; Sun, S.D.; Fabijanic, D.; Gallo, S.C.; Leary, M.; Easton, M.; Brandt, M. The effect of heat treatment on the abrasive and erosive wear behaviour of laser metal deposited Fe-28Cr-2.7C alloy. Wear 2020, 458-459, 203410. [CrossRef]

37. Chatterjee, S.; Pal, T.K. Solid particle erosion behaviour of hardfacing deposits on cast iron-Influence of deposit microstructure and erodent particles. Wear 2006, 261, 1069-1079. [CrossRef]

38. Aldi, N.; Casari, N.; Pinelli, M.; Suman, A.; Vulpio, A.; Saccenti, P.; Beretta, R.; Fortini, A.; Merlin, M. Erosion behavior on a large-sized centrifugal fan. In Proceedings of the 13th European Turbomachinery Conference on Turbomachinery Fluid Dynamics and Thermodynamics, ETC 2019, Lausanne, Switzerland, 8-12 April 2019.

39. ASTM G76. Standard Test Method for Conducting Erosion Tests by Solid Particle Impingement Using Gas Jets; ASTM International: West Conshohocken, PA, USA, 2012.

40. Calvert, G.; Ghadiri, M.; Tweedie, R. Aerodynamic dispersion of cohesive powders: A review of understanding and technology. Adv. Powder Technol. 2009, 20, 4-16. [CrossRef] 
41. Suman, A.; Vulpio, A.; Fortini, A.; Fabbri, E.; Casari, N.; Merlin, M.; Pinelli, M. Experimental analysis of micro-sized particles time-wise adhesion: The influence of impact velocity and surface roughness. Int. J. Heat Mass Transf. 2021, 165, 120632. [CrossRef]

42. Lin, C.-M.; Chang, C.-M.; Chen, J.-H.; Wu, W. The effects of additive elements on the microstructure characteristics and mechanical properties of Cr-Fe-C hard-facing alloys. J. Alloys Compd. 2010, 498, 30-36. [CrossRef]

43. Raynor, G.V.; Rivlin, V.G. Phase Equilibria in Iron Ternary Alloys: A Critical Assessment of the Experimental Literature; CRC Press: Boca Raton, FL, USA, 1988; ISBN 978-0901462343.

44. Jilleh, A.; Kishore Babu, N.; Thota, V.; Anis, A.L.; Harun, M.K.; Talari, M.K. Microstructural and wear investigation of high chromium white cast iron hardfacing alloys deposited on carbon steel. J. Alloys Compd. 2021, 857, 157472. [CrossRef]

45. Berns, H.; Fischer, A. Microstructure of Fe-Cr-C hardfacing alloys with additions of Nb, Ti and, B. Mater. Charact. 1997, 39, 499-527. [CrossRef]

46. Wang, X.; Han, F.; Liu, X.; Qu, S.; Zou, Z. Microstructure and wear properties of the Fe-Ti-V-Mo-C hardfacing alloy. Wear 2008, 265, 583-589. [CrossRef]

47. Leško, A.; Navara, E. Microstructural characterization of high-carbon ferrochromium. Mater. Charact. 1996, 36, 349-356. [CrossRef]

48. Liu, S.; Zhou, Y.; Xing, X.; Wang, J.; Ren, X.; Yang, Q. Growth characteristics of primary $\mathrm{M}_{7} \mathrm{C}_{3}$ carbide in hypereutectic Fe-Cr-C alloy. Sci. Rep. 2016, 6, 32941. [CrossRef] [PubMed]

49. Guitar, M.A.; Scheid, A.; Suárez, S.; Britz, D.; Guigou, M.D.; Mücklich, F. Secondary carbides in high chromium cast irons: An alternative approach to their morphological and spatial distribution characterization. Mater. Charact. 2018, 144, 621-630. [CrossRef]

50. Doğan, Ö.N.; Hawk, J.A. Effect of carbide orientation on abrasion of high Cr white cast iron. Wear 1995, 189, 136-142. [CrossRef]

51. Chotěborský, R.; Hrabě, P.; Müller, M.; Válek, R.; Savková, J.; Jirka, M. Effect of carbide size in hardfacing on abrasive wear. Res. Agric. Eng. 2009, 55, 149-158. [CrossRef]

52. Lai, J.P.; Pan, Q.L.; Wang, Z.B.; Cui, H.R.; Wang, X.D.; Gao, Z.Z. Effects of destabilization temperature on the microstructure and mechanical properties of high chromium cast iron. J. Mater. Eng. Perform. 2017, 26, 4667-4675. [CrossRef]

53. Pawar, S.; Jha, A.K.; Mukhopadhyay, G. Effect of different carbides on the wear resistance of Fe-based hardfacing alloys. Int. J. Refract. Met. Hard Mater. 2019, 78, 288-295. [CrossRef]

54. Gucwa, M.; Winczek, J.; Parzych, S.; Kukuryk, M. The effect of the hardfacing processes parameters on the carbide volume fraction. In Lecture Notes in Mechanical Engineering; Springer: Lutsk, Ukraine, 2019; pp. 410-417. [CrossRef] 